\title{
One millisecond of light suffices to suppress nighttime pineal melatonin synthesis in rats
}

\author{
L. Vollrath ${ }^{1}$, A. Seidel ${ }^{1}$, A. Huesgen ${ }^{1}$, B. Manz ${ }^{2}$, K. Pollow ${ }^{2}$ and P. Leiderer ${ }^{3}$ \\ 'Institule of Anatomy. 'Department of Experimental Endocrinology and Institute of Physics, Johames \\ Gutenberg University. Mainz (F.R.G.)
}

(Received 7 December 1988; Accepted 7 December 1988)

Key words: Rat: Pineal gland; Melatonin synthesis; Light exposure

The effect of a single high-intensity light pulse with a duration of $1 \mathrm{~ms}$ on nighttime pineal activity of male Sprague-Dawley rats was investigated. 10 minutes after light exposure pineal $\mathrm{N}$-actyltransferase activity and melatonin content were significantly reduced. These results show that the rat pineal is capable of responding to very short light flashes of high intensity.

In numerous experiments it has been demonstrated that the biosynthetic activity of the mammalian pineal gland is controlled by environmental light. This environmental cue acts through the retinal-hypothalamic pathway and is mediated by the sympathetic innervation of the pineal gland [4]. When rats or Syrian hamsters are exposed during the dark phase to artificial light for $1 \mathrm{~min}$ or less, both pineal $\mathrm{N}$-acetyltransferase (NAT) activity and melatonin content are rapidly decreased $[2,5,7$, 9]. However. electrophysiological studies have shown that the mammalian retina responds to light pulses much shorter than $1 \mathrm{~s}[10]$. This prompted us to investigate the effect of a light flash of $1 \mathrm{~ms}$ on pineal activity in rats.

Male Sprague-Dawley rats with a body weight between 365 and $465 \mathrm{~g}$ were obtained from a commercial breeder. After arrival the animals were kept under routine laboratory conditions for 4 weeks ( $12 \mathrm{~h}$ light-12 h dark; lights on at $07.00 \mathrm{~h}$; white fluorescent strip light; $200 \mathrm{I} \times$ at cage level). Six $\mathrm{h}$ after the onset of darkness 7 rats were exposed to a light pulse produced by a commercial photographic flash light. The duration of this flash was $1 \mathrm{~ms}$ as measured by a PIN-photodiode connected to a storage oscilloscope (GOULD 4035). Intensity was $2000 \mathrm{mWs} / \mathrm{cm}^{2}$ at cage level. Ten min later the rats were sacrificed by decapitation. Six untreated rats killed under dim red light $\left(<1.5 \mu \mathrm{W} / \mathrm{cm}^{2}\right)$ served as controls. The pineal was rapidly removed and cut in half. One half of the gland was processed and reserved for future electronmicroscopic studies. The other half was frozen in liquid nitrogen and $8 \mathrm{~h}$ later sonicated in $60 \mu \mathrm{l} 50 \mathrm{mmol} / \mathrm{l}$ phosphate buffer $\mathrm{pH} 6.5$. NAT activity was measured

Correspondence: L. VolJrath, Anatomisches Institut, Johannes Gutenberg Universität, 6500 Mainz, F.R.G.

Konstanzer Online-Publikations-System (KOPS)

URL: http://www.ub.uni-konstanz.de/kops/volltexte/2007/3184/

URN: http://nbn-resolving.de/urn:nbn:de:bsz:352-opus-31840 
as described by Deguchi and Axelrod [2]. Pineal melatonin levels were assessed by radioimmunoassay [1] and protein content was measured as described by Lowry et al. [6]. Means were compared by Student's $t$-test.

Means were compared by Student's $t$-test.

Light exposure reduced the pineal NAT-activity significantly $(P<0.01)$ from $84.6 \pm 18.9 \mathrm{nmol} \cdot \mathrm{mg}$ protein ${ }^{-1} \cdot \mathrm{h}^{-1}\left(\right.$ mean \pm S.E.M.) to $6.4 \pm 1.6 \mathrm{nmol} / \mathrm{mg}$ protein ${ }^{-1}$. $\mathrm{h}^{-1}$. Melatonin levels dropped from $18.0 \pm 1.7$ to $0.21 \pm 0.07 \mathrm{ng} \mathrm{mg}$ protein $^{-1}$ $(P<0.01)$.

The reduction of pineal melatonin synthesis found in our study was similar to the suppression in response to much longer light pulses of $0.1 \mathrm{~min}$ in rats [5] and to a 5- or I-s light pulse of very high intensity in Syrian hamsters [9]. In a study by Minnemann et al. [8] the minimum intensity which affected pineal melatonin content during 30 min exposure was $0.11 \mu \mathrm{W} / \mathrm{cm}^{2}$, corresponding to a total radiation efflux of approximately $200 \mu \mathrm{Ws} / \mathrm{cm}^{2}$. In our study, the rats received about ten times as much radiation within one millisecond. The suppression of NAT-activity and pineal melatonin content shows that the rat pineal is capable of responding to extremely short light flashes of high intensity. This supports earlier suggestions [11] that in rats a certain amount of radiation energy is necessary to affect pineal function, independent of the duration of exposure.

The technical assistance of $\mathrm{R}$. Lieberth is gratefully acknowlegded. This study was supported by the Deutsche Forschungsgemeinschaft Vo 135/8-5.

1 Althaus, U., Manz, B. and Pollow, K., Direct radioimmunoassay ( ${ }^{125}$ I) of free mclatonin in saliva (abstract), Acta endocrinol., 283 (1987) 65.

2 Brainard, G.C., Richardson, B.A., King, T.S., Matthews, S.A. and Reiter, R.J., The suppression of pineal melatonin content and $\mathrm{N}$-acetyltransferase activity by different light irradiances in the Syrian hamster: a dose-response relationship, Endocrinology, 113 (1983) 293-296.

3 Deguchi, T. and Axelrod, J., Sensitive assay for serotonin $\mathrm{N}$-acetyl-transferase activity in the rat pineal gland, Anal. Biochem.. 50 (1972) 174-179.

4 Klein. D.C. and Moore, R.Y., Pincal $N$-acetyltransferase and hydroxyindole- $O$-methyltransferase: control by the suprachiasmatic nucleus, Brain Res., 174 (1979) 245-262.

5 Illnerová, H. and Vaněček, J., Response of rat pineal serotonin $N$-acetyltransferase to onc minute light pulse at different night times, Brain Res., 167 (1979) 431-434.

6 Lowry, O.H., Rosebrough, N.J., Farr, A.L. and Randall, R.J., Protein measurement with the Folin phenol reagent, J. Biol. Chem., 193 (1951) 265-275.

7 Lynch, H.J., Deng, M.-H. and Wurtman, R.J., Light intensities required to suppress nocturnal melatonin secretion in albino and pigmented rats, Life Sci., 35 (1984) 841-847.

8 Minneman, K.P., Lynch, H. and Wurtman, R.J., Relationship between environmental light intensity and retinal-mediated suppression of rat pineal serotonin $\mathrm{N}$-acetyltransferase, Life Sci., 15 (1974) 17911796.

9 Reiter, R.J., Joshi, B.N., Heinzeller, T. and Nürnberger, F., A single 1-or 5-second light pulse at night inhibits hamster pineal melatonin, Endocrinology, 118 (1986) 1906-1909.

10 Reuter, J.H., A comparison of flash evoked ERGs and ERGs evoked with sinusoidally modulated light stimuli in a number of rodents, Pflügers Arch.. 331 (1972) 95-102.

11 Vaněček, J. and Illnerová, $\mathrm{H}$., Night pineal $\mathrm{N}$-acetyltransferase activity in rats exposed to white and red light pulses of various intensity and duration, Experientia, 38 (1982) 1318-1320. 